\title{
A New Sesquiterpene from Trichilia casarettii (Meliaceae)
}

\author{
Ivo José Curcino Vieira ${ }^{1,2 *}$, Elaine Rodrigues Figueiredo², Virginia Rodrigues Freitas ${ }^{2}$, \\ Leda Mathias ${ }^{1}$, Raimundo Braz-Filho ${ }^{3}$, Renata Mendonça Araújo ${ }^{4}$ \\ ${ }^{1}$ Laboratório de Ciências Químicas-CCT, Universidade Estadual do Norte Fluminense Darcy Ribeiro, \\ Campos dos Goytacazes, Brazil \\ ${ }^{2}$ Laboratório de Tecnologia de Alimentos-CCTA, Universidade Estadual do Norte Fluminense Darcy Ribeiro, \\ Campos dos Goytacazes, Brazil \\ ${ }^{3}$ Universidade Estadual do Norte Fluminense Darcy Ribeiro, Campos dos Goytacazes, Brazil \\ ${ }^{4}$ Departamento de Química-CCET, Universidade Federal do Rio Grande do Norte, Natal, Brazil \\ E-mail: curcino@uenf.br
}

Received July 1, 2010; revised July 27, 2010; accepted August 2, 2010

\begin{abstract}
The dichloromethane extract of the air-dried stems of Trichilia casarettii afforded a new sesquiterpene (1), lupeol, stigmasterol, campesterol and sitosterol. The structure of 1 was elucidated by extensive one-and twodimensional nuclear magnetic resonance and mass spectrometry.
\end{abstract}

Keywords: Trichilia Casarettii, Meliaceae, Sesquiterpene

\section{Introduction}

The Meliaceae family has attracted much interest among bioproduction phytochemists because of its very complex and diverse chemical structures and its biological activity, mainly against insects [1-3]. The Trichilia genus (Meliaceae) includes about 230 species distributed throughout tropical America which are recognized for their significant economic importance and high commercial value. The genus is rich in terpenoids, including triterpenes, limonoids, steroids and other terpenes derivatives [3-5].

In previous the activity of aqueous extract of leaves and twigs from T. casarettii was evaluated on Spodoptera frugiperda (J. E. Smith) development in laboratory conditions [6]. To the best of our knowledge, the literature reports no chemical investigation evaluation of $T$. casarettii native of Americas [7]. This stimulated our interest in the present work, involving isolation and structural elucidation of the constituents of the stems of this species. Then, we report the isolation of new sesquiterpene 1 (Figure 1) of $T$. casarettii DC. The stems also afforded lupeol, stigmasterol, campesterol, sitosterol and fatty acid esters.

The stems from T. casarettii DC., was collected on November 2006, at Vale do Rio Doce Cia., Linhares City, Espírito Santo State, Brazil. A voucher specimen $\left(\mathrm{N}^{\mathrm{o}} 449\right)$ was deposited at Vale do Rio Doce Cia. Herbarium.

\section{Results and Discussion}

Comound 1 (Figure 1) was obtained as white powder $(\mathrm{MeOH}), \mathrm{mp} 121-122^{\circ} \mathrm{C}$, and which is optically active with an $[\alpha]_{D}^{23}=-18.1^{\circ}\left(\mathrm{CHCl}_{3}, c 0.002\right)$. Its IR spectrum (KBr disk) obtained in spectrometer Shimadzu, model FTIR-8300, showed bands at $v_{\max } 3433$ (O-H stretching), 3394 (O-H stretching) $\mathrm{cm}^{-1}$. Comparative analysis using spectrometer Brüker, DRX model [(operating at $400\left({ }^{1} \mathrm{H}\right)$ and $100\left({ }^{13} \mathrm{C}\right) \mathrm{MHz}$, respectively, in pyridine- $\left.\left.d_{5}\right)\right]$ of the $\left\{{ }^{1} \mathrm{H}\right\}$ - and DEPT $135^{\circ}{ }_{-}^{13} \mathrm{C}$ NMR spectra (Table 1) revealed signals corresponding to 15 carbon atoms. These data allowed us to recognize the presence of signals corresponding to three nonhydrogenated carbons $\left[(\mathrm{C})_{3}:\right.$ all sp ${ }^{3}$ (including two bound to an oxygen atoms at $\delta_{\mathrm{C}} 71.51$ and 71.58)], two methine $\left[(\mathrm{CH})_{2}\right.$ : all sp ${ }^{3}$, two $\alpha$ to a carbinolic carbon atom at $\delta_{\mathrm{C}} 55.64 / \delta_{\mathrm{H}} 1.58$ and $\delta_{\mathrm{C}} 51.14 / \delta_{\mathrm{H}} 1.60$, correlated in the HMQC spectrum with ${ }^{1} \mathrm{H}$ chemical

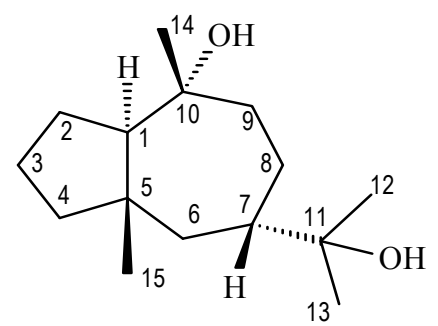

Figure 1. Chemical structure of ambrosanoli-10, 11-diol (1). 
Table $1 .{ }^{13} \mathrm{C}(100 \mathrm{MHz})$ and ${ }^{1} \mathrm{H}$ NMR (400 MHz) data of compound 1 in pyridine- $d_{5}, \delta$ in ppm, $J$ in $\mathrm{Hz}$ and multiplicities, in parenthesis.*

\begin{tabular}{|c|c|c|c|c|}
\hline \multirow[b]{2}{*}{$\mathbf{C}$} & \multicolumn{2}{|c|}{ HMQC } & \multicolumn{2}{|c|}{ HMBC } \\
\hline & $\delta_{\mathrm{C}}$ & $\delta_{\mathrm{H}}$ & ${ }^{2} J_{\mathrm{CH}}$ & ${ }^{3} J_{\mathrm{CH}}$ \\
\hline 5 & 35.08 & - & $2 \mathrm{H}-4 ; 3 \mathrm{H}-15$ & $\mathrm{H}-7$ \\
\hline 10 & 71.51 & - & $2 \mathrm{H}-9 ; 3 \mathrm{H}-14$ & \\
\hline 11 & 71.58 & - & H-7; 3H-12; 3H-13 & \\
\hline \multicolumn{5}{|l|}{$\mathrm{CH}$} \\
\hline 1 & 55.64 & $1.60-1.52(\mathrm{~m})$ & & $2 \mathrm{H}-9 ; 3 \mathrm{H}-14 ; 3 \mathrm{H}-15$ \\
\hline 7 & 51.14 & $1.62-1.54(\mathrm{~m})$ & & $3 \mathrm{H}-12 ; 3 \mathrm{H}-13$ \\
\hline \multicolumn{5}{|c|}{$\mathrm{CH}_{2}$} \\
\hline 2 & 21.01 & $\begin{array}{l}1.60-1.56(\mathrm{~m}) \\
1.54-1.50(\mathrm{~m})\end{array}$ & & \\
\hline 3 & 23.47 & $\begin{array}{c}1.85(\mathrm{br} \mathrm{s}, 11.0) \\
1.60-1.57(\mathrm{~m})\end{array}$ & $2 \mathrm{H}-2 ; 2 \mathrm{H}-4$ & \\
\hline 4 & 45.77 & $\begin{array}{l}1.44-1.40(\mathrm{~m}) \\
1.14-1.12(\mathrm{~m})\end{array}$ & $2 \mathrm{H}-3$ & $3 \mathrm{H}-15$ \\
\hline 6 & 42.08 & $\begin{array}{l}1.38-1.36(\mathrm{~m}) \\
1.10-1.02(\mathrm{~m})\end{array}$ & & $2 \mathrm{H}-4 ; 3 \mathrm{H}-15$ \\
\hline 8 & 22.58 & $\begin{array}{c}2.64(\mathrm{br} \mathrm{s}, 12.0) \\
1.39-1.37(\mathrm{~m})\end{array}$ & & \\
\hline 9 & 44.55 & $\begin{array}{c}1.98(\mathrm{br} \mathrm{s}, 12.0) \\
1.75-1.78(\mathrm{~m})\end{array}$ & & $3 \mathrm{H}-14$ \\
\hline \multicolumn{5}{|c|}{$\mathrm{CH}_{3}$} \\
\hline 12 & 28.24 & $1.38(\mathrm{~s})$ & & $\mathrm{H}-7 ; 3 \mathrm{H}-13$ \\
\hline 13 & 28.20 & $1.38(\mathrm{~s})$ & & $\mathrm{H}-7 ; 3 \mathrm{H}-12$ \\
\hline 14 & 23.51 & $1.31(\mathrm{~s})$ & & 2H-9 \\
\hline 15 & 19.56 & $0.93(\mathrm{~s})$ & & $2 \mathrm{H}-4 ; 2 \mathrm{H}-6$ \\
\hline
\end{tabular}

shifts, respectively], six methylene $\left[\left(\mathrm{CH}_{2}\right)_{6}\right.$, including one $\alpha$ to a carbinolic carbon atom at $\delta_{\mathrm{C}} 44.55 / \delta_{\mathrm{H}} 1.98$ and 1.72] and four methyl $\left[\left(\mathrm{CH}_{3}\right)_{4}\right.$ : including three linked to a carbinolic carbon atom at $\delta_{\mathrm{C}} 28.24 / \delta_{\mathrm{H}} 1.38, \delta_{\mathrm{C}} 28.20 / \delta_{\mathrm{H}}$ 1.38 and $\left.\delta_{\mathrm{C}} 23.51 / \delta_{\mathrm{H}} 1.31\right]$ carbon atoms, allowing us to deduce the expanded molecular formulae $(\mathrm{C})(\mathrm{C}-\mathrm{OH})_{2}$ $(\mathrm{CH})_{2}\left(\mathrm{CH}_{2}\right)_{6}\left(\mathrm{CH}_{3}\right)_{4}=\mathrm{C}_{15} \mathrm{H}_{28} \mathrm{O}_{2}$ for $\mathbf{1}$. The high-resolution electrospray ionization mass spectra (HR-ESIMS) of 1 obtained in mass spectrometer, model LCMS-IT-TOF (225- 07100-34, Shimadzu) showed a pseudomolecular ion at $\mathrm{m} / \mathrm{z} 263.1988[\mathrm{M}+\mathrm{Na}]^{+}$, with the calculated value for $\mathrm{C}_{15} \mathrm{H}_{28} \mathrm{O}_{2} \mathrm{Na}$ being 263.1987. The molecular formula indicated an index of hydrogen deficiency of two. Thus, with ${ }^{1} \mathrm{H}$ and ${ }^{13} \mathrm{C}$ NMR spectral data and the compound bicyclic is compatible with the carbon skeleton sesquiterpenic of the ambrosanolide type [8].

In the ${ }^{1} \mathrm{H}$ NMR spectrum, three singlet signals were observed at $\delta_{\mathrm{H}} 1.38$ and $\delta_{\mathrm{H}} 1.31$, characteristic of a methyl groups linked to two carbinolic carbons, and one singlet signal at $\delta_{\mathrm{H}} 0.93$, corresponding to the signals at $\delta_{\mathrm{C}} 28.24\left(\mathrm{CH}_{3}-12\right), 28.20\left(\mathrm{CH}_{3}-13\right), 23.51\left(\mathrm{CH}_{3}-14\right)$ and $19.56\left(\mathrm{CH}_{3}-15\right)$ in the ${ }^{13} \mathrm{C}$ NMR spectrum, suggesting the presence of two hydroxyl groups. The HMBC spectrum allowed us to confirm these long-range correlations (Table 1) through the signals corresponding to $\mathrm{C}-10\left(\delta_{\mathrm{C}}\right.$
$71.51)$ with the singlet observed at $\delta_{\mathrm{H}} 1.31\left(3 \mathrm{H}-14,{ }^{2} J_{\mathrm{CH}}\right)$ and $\mathrm{C}-11\left(\delta_{\mathrm{C}} 71.58\right)$ with the two singlets observed at $\delta_{\mathrm{H}}$ $1.38\left(3 \mathrm{H}-12\right.$ and $\left.3 \mathrm{H}-13,{ }^{2} J_{\mathrm{CH}}\right)$. This deduction was corroborated by the long-range correlations of methyne carbons $\mathrm{CH}-1\left(\delta_{\mathrm{C}} 55.64\right)$ with both $3 \mathrm{H}-14$ and $3 \mathrm{H}-15\left(\delta_{\mathrm{H}}\right.$ 1.31 and $\left.0.93,{ }^{3} J_{\mathrm{CH}}\right)$ and $\mathrm{CH}-7\left(\delta_{\mathrm{C}} 51.14\right)$ with both $3 \mathrm{H}-12$ and $3 \mathrm{H}-13\left(\delta_{\mathrm{H}} 1.38,{ }^{3} J_{\mathrm{CH}}\right)$ observed in the HMBC spectrum (Table 1). Thus, these data allowed us to recognize the presence of hydroxyl groups at $\mathrm{C}-10\left(\delta_{\mathrm{C}} 71.51\right)$ and $\mathrm{C}-11\left(\delta_{\mathrm{C}} 71.58\right)$.

The relative stereochemistry of $\mathbf{1}$ was determined from the spatial dipolar interaction revealed by the ${ }^{1} \mathrm{H}-{ }^{1} \mathrm{H}-$ NOESY spectrum, summarized in Figure 2. The ${ }^{1} \mathrm{H}-{ }^{1} \mathrm{H}-$ NOESY spectrum of $\mathbf{1}$ allowed characterization of the ring-junction (CH-1 with $\mathrm{C}-5)$ of the bicyclic system involving the seven and five-rings as trans. The relative stereochemistry indicated in $\mathbf{1}$ was deduced by the spatial dipolar interaction observed in the ${ }^{1} \mathrm{H}-{ }^{1} \mathrm{H}-\mathrm{NOESY}$ spectrum between hydrogen atom $\mathrm{H}-7$ with $\mathrm{H}_{3}-14$ and $\mathrm{H}_{3}-15$ indicating that both are $\beta$-oriented. The spatial dipolar interaction observed between $\mathrm{H}-1$ and $\mathrm{H}-6 \mathrm{~b}$ and absence of spatial interaction between $\mathrm{H}-1$ with both, $\mathrm{H}_{3}-14$ and $\mathrm{H}_{3}-15$, respectively, indicating that $\mathrm{H}-1$ was $\alpha$-oriented in agreement with a trans ring-junction. 


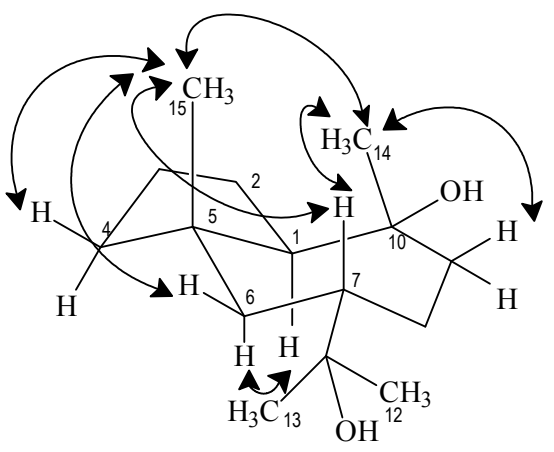

Figure 2. Selected NOESY correlations and relative stereochemistry for compound 1. Arrows denote the main NOESY correlations.

Additional spatial interaction is shown in Figure 2. Therefore, the structure of the new sesquiterpene (Figure 1) isolated from $T$. casarettii was defined as ambrosanoli-10,11-diol (1) (30 mg, 0.0433\%).

The structures of lupeol [9], $\beta$-sitosterol [10] and stigmasterol [10] were deduced by comparison of their ${ }^{1} \mathrm{H}$ and ${ }^{13} \mathrm{C}$ NMR spectral data with those reported in the literature.

\section{Acknowledgements}

The authors are grateful to Fundação de Amparo à Pesquisa do Estado do Rio de Janeiro (FAPERJ) for grants and to Conselho Nacional de Desenvolvimento Científico (CNPq-Brazil) for a research fellowship and grants.

\section{References}

[1] Y. S. Xie, M. B. Isman, P. Gunning, S. Mackinnon, J. T. Arnason, D. R. Taylor, P. Sánchez, C. Hasbun and G. H. N. Towers, "Biological Activity of Extracts of Trichilia Species and the Limonoid Hirtin against Lepidopteran
Larvae," Biochemical Systematics and Ecology, Vol. 22, No. 2, March 1994, pp. 129-136.

[2] T. D. Pennington and B. D. Styles, "A Generic Monograph of Meliaceae," Blumea, Vol. 22, No. 3, AugustDecember 1975, pp. 419-540.

[3] M. T. Pupo, P. C. Vieira, J. B. Fernandes, M. F. G. F. Silva and J. R. Pirani, "Terpenoids and Steroids from Trichilia Species," Journal of the Brazilian Chemical Society, Vol. 13, No. 3, June 2002, pp. 382-388.

[4] M. C. Ramírez, R. A. Toscano, J. Arnason, S. Omar, C. M. Cerda-Garcia-Rojas and R. Mata, "Structure, Conformation and Absolute Configuration of New Antifeedant Dolabellanes from Trichilia trifolia," Tetrahedron, Vol. 56, No. 29, July 2000, pp. 5085-5091.

[5] D. A. G. Cortez, J. B. Fernandes, P. C. Vieira, M. F. G. F. Silva, A. G. Ferreira, Q. B. Cass and J. R. Pirani, "Meliacin Butenolides from Trichilia estipulata," Phytochemistry, Vol. 49, No. 8, December 1998, pp. 2493-2496.

[6] P. C. Bogorni and J. D. Vendramim, "Sublethal Effect of Aqueous Extracts of Trichilia spp. on Spodoptera frugiperda (J. E. Smith) (Lepidoptera: Noctuidae) Development on Maize," Neotropical Entomolology, Vol. 34, No. 2, March/April 2005, pp. 311-317.

[7] P. C. Patrício and A. C. Cervi, "O Gênero Trichilia P. Browne (Meliaceae) no estado do Paraná, Brasil," Acta Biologica Paranaense, Vol. 34, No. 1-4, January/April 2005, pp. 27-71.

[8] A. U. Rahman and V. U. Ahmad, “"13 C-NMR of Natural Products: Monoterpenes and Sesquiterpenes," Hussain Ebrahim Jamal Research Institute of Chemistry, University of Karachi, Pakistan, Vol. 1, 1992.

[9] V. U. Ahmad and A. U. Rahman, "Handbook of Natural Products Data, Pentacyclic Triterpenoids," Elsevier Press, Karachi, Vol. 2, 1994.

[10] N. P. Rai, B. B. Adhikari, A. Paudel, K. Masuda, R. D. Mckelvey and M. D. Madandhar, "Phytochemical Constituents of the Flowers of Sarcococca coriacea of Nepalese Origin," Journal of Nepal Chemical Society, Vol. 21, 2006, pp. 1-7. 